\title{
RSEARCANIS Si \\ PHYSICALAC NID \\ Analysis of running phase during triathlon and aquathlon competition in young athletes
}

Autor(es): $\quad$ Comotto, S.; Capranica, L.; Piacentini, M. F.

Publicado por: Imprensa da Universidade de Coimbra

URL persistente:

URI:http://hdl.handle.net/10316.2/3377

DOI:

DOI:http://dx.doi.org/10.14195/2182-7087_2_13

Accessed : $\quad$ 26-Apr-2023 10:43:46

A navegação consulta e descarregamento dos títulos inseridos nas Bibliotecas Digitais UC Digitalis, UC Pombalina e UC Impactum, pressupõem a aceitação plena e sem reservas dos Termos e Condições de Uso destas Bibliotecas Digitais, disponíveis em https://digitalis.uc.pt/pt-pt/termos.

Conforme exposto nos referidos Termos e Condições de Uso, o descarregamento de títulos de acesso restrito requer uma licença válida de autorização devendo o utilizador aceder ao(s) documento(s) a partir de um endereço de IP da instituição detentora da supramencionada licença.

Ao utilizador é apenas permitido o descarregamento para uso pessoal, pelo que o emprego do(s) título(s) descarregado(s) para outro fim, designadamente comercial, carece de autorização do respetivo autor ou editor da obra.

Na medida em que todas as obras da UC Digitalis se encontram protegidas pelo Código do Direito de Autor e Direitos Conexos e demais legislação aplicável, toda a cópia, parcial ou total, deste documento, nos casos em que é legalmente admitida, deverá conter ou fazer-se acompanhar por este aviso. 
(2) 2011

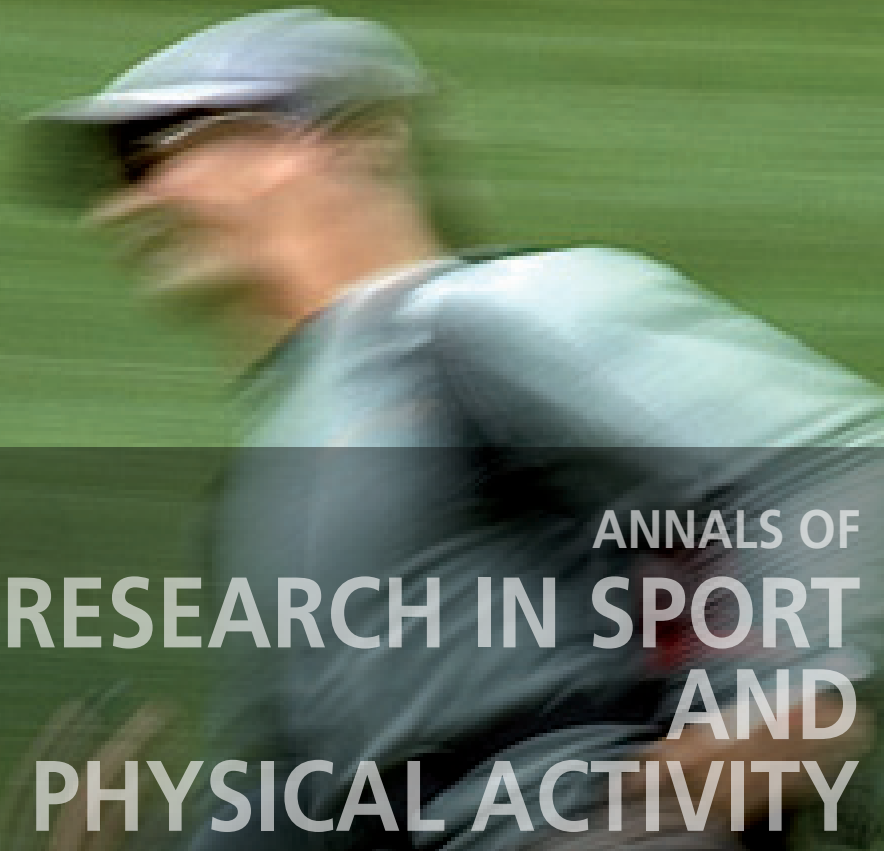

FACULDADE DE

CIÊNCIAS DO

DESPORTO E

EDUCAÇÃO FÍSICA DA UNIVERSIDADE DE COIMBRA

IMPRENSA

DA UNIVERISDADE

DE COIMBRA 
2・SPORT TRAINING

ANALYSIS OF RUNNING PHASE DURING TRIATHLON AND AQUATHLON COMPETITION IN YOUNG ATHLETES 


\section{PURPOSE}

This study evaluated the last running-phase during triathlon and aquathlon competitions in young athletes.

\section{METHODS}

Four Youth athletes $(M=2 ; F=2 ; 16 \pm 1 y r s)$ participating in both triathlon (running-phase $1600 \mathrm{~m}$ ) and aquathlon (running-phase 2000m) Italian championships took part in the present study. A wearable GPS (SPY-ProX, GPSSport, 15hrz) was used to record individual velocities and distance covered. To evaluate pacing-strategy, fractions of $200 \mathrm{~m}$ mean distance were considered. ANOVA for repeated measures was used to evaluate pacing-strategy, and a student paired T-test was used to verify speed differences between triathlon and aquathlon $(\mathrm{P}<0.05)$.

\section{RESULTS}

Running during triathlon showed a $19 \%$ non significant decrement during the last $200 \mathrm{~m}$. Conversely, during aquathlon, athletes adopted a negative pacing-strategy with an increase of $15 \%$ in velocity between the first and the last $200 \mathrm{~m}$.

Differences between races emerged only at $1200 \mathrm{~m}(3.6 \pm 0.6 \mathrm{~m} / \mathrm{s}$ for triathlon and $4.1 \pm 0.6 \mathrm{~m} / \mathrm{s}$ for aquathlon) and $1400 \mathrm{~m}(3.6 \pm 0.7 \mathrm{~m} / \mathrm{s}$ and $4.1 \pm 0.8 \mathrm{~m} / \mathrm{s}$, respectively).

\section{DISCUSSION}

To our knowledge, this is the first study to evaluate differences in triathlon and aquathlon running-phase. Athletes adopted a different pacing-strategy in the two races, with a trend of higher running velocities in aquathlon compared to triathlon. Further research is needed to investigate the effects of cycling or swimming on the last running phase.

\footnotetext{
1 University of Rome "Foro Italico", Italy; e-mail: stefania.comotto@uniroma4.it.
} 